\title{
Driving with the handbrake on: competition class actions under the Consumer Rights Act 2015
}

\begin{abstract}
Andrew Higgins*
This paper examines the new class action procedure for competition cases established by the Consumer Rights Act 2015. It examines whether the legislation and the procedural rules for the Competition Appeal Tribunal address the failures of previous procedures, focusing on three issues in particular i) the treatment of conflicting interests amongst class members ii) the rules on certifying collective proceedings; and iii) rules on funding. It argues that while the Act is a considerable improvement on what preceded it, the safeguards adopted will act as a drag on meritorious and unmeritorious claims alike, and as such there is likely to be continued under-enforcement of competition law.
\end{abstract}

\section{INTRODUCTION}

In March 2015 the UK parliament passed the first opt-out class action procedure in English law, specifically for competition cases before the Competition Appeal Tribunal (Hereafter CAT or 'the Tribunal'). The procedure is set out in Schedule 8 of the Consumer Rights Act 2015 (supplemented by new rules of procedure for the $\mathrm{CAT}^{1}$ ), which amends the relevant parts of the Competition Act 1998 and the Enterprise Act 2002. ${ }^{2}$ The Act contains several features considered essential if victims of competition law breaches are to obtain collective redress. It permits opt-out damages actions to be brought directly by an (alleged) victim of a competition law breach, on behalf of similarly situated persons, either to establish liability or in a 'follow on' action where an authorised body has already made a finding of liability. It also permits the Tribunal to make an aggregate damages award to the class, ie to award damages without undertaking an assessment of damages recoverable by each individual class member. Despite strong opposition to class actions amongst business lobby groups, and concern about the spectre of 'US style' litigation, the Government pressed ahead with the reforms partly because it considered 'the current system of collective redress does not work'. ${ }^{3}$ On the other hand, the Government introduced 'safeguards' into the new class

\footnotetext{
* Associate Professor in Civil Procedure, Faculty of Law and Mansfield College, University of Oxford. The author would like to thank Adrian Zuckerman and the two anonymous referees for their comments on this article. The usual disclaimers apply.
} 
action procedure, ${ }^{4}$ including a strong certification process, a prohibition on exemplary damages and a prohibition on damages based agreements in opt-out class actions.

The design of the new procedure reflects the Government's desire to balance the need to make collective redress available and viable in a wider range of cases and avoid abuse of the system. ${ }^{5}$ The legislation has been called a 'third generation' statute designed to incorporate the lessons learnt from other jurisdictions with opt-out class actions including the United States, Australia and Canada. ${ }^{6}$

A number of aspects of the new class action procedure merit detailed review including the role of alternative dispute resolution, and how the Tribunal should exercise its power to award aggregate damages. However, this article focuses on three issues: the treatment of conflicting interests between class members, the certification criteria for class actions and the rules on funding The article's central claim is that while the new procedure is a welcome improvement on existing mechanisms, the success of the reforms will require a change in judicial attitudes as to the types of disputes that are suitable for collective resolution, and would benefit from further legislative refinement. The procedure is ambiguous on the treatment of class conflicts that proved fatal to previous procedures, and the 'safeguards' built into the system are likely to deter both meritorious and unmeritorious claims. In this regard it is unfortunate that some of the key lessons of Lord Justice Jackson's landmark costs review in $2009^{7}$ have not been incorporated into the design of the new procedure.

\footnotetext{
${ }^{1}$ Competition Appeal Tribunal Rules 2015, Part V, 'Collective Proceedings and Collective Settlements'.

${ }^{2}$ Consumer Rights Act 2015, sched 8 'Private Actions in Competition Law'. All references in this article to 'the Act' are references to the Competition Act as amended.

${ }^{3}$ Department for Business Innovation and Skills (BIS), Private Actions in Competition Law: A Consultation on Options for Reform: Government Response (London: BIS, 2013) at [5.12].

${ }^{4}$ ibid, at [5.13].

${ }^{5}$ BIS, Private Action in Competition Law: A Consultation on Options for Reform (London: BIS, 2012) 30-31.

${ }^{6}$ Presentation by Professor Rachael Mulheron, 'Consumer Rights Act 2015 - The UK Class Action: A Reaction' at the British Institute of International and Comparative Law, 21 April 2015.
}

${ }^{7}$ R. Jackson, Review of civil litigation costs: final report (London: TSO, 2009). 


\section{BACKGROUND AND MAIN FEATURES OF THE NEW CLASS ACTION PROCEDURE}

The value of collective action in litigation is generally well understood. Joining forces with others in the same predicament can lead to much more effective use of resources and economies of scale, and help provide individuals and businesses with effective redress for claims that would not otherwise be viable. Effective private enforcement can complement public enforcement, thereby promoting greater levels of compliance if one accepts the empirical assumption that compliance rates are at least partly influenced by the probability of enforcement of the relevant standard. As the Office of Fair Trading stated in its submission on the Government's Consumer Rights Bill:

If a greater number of well-founded opt-out actions are brought, incentives to comply with competition law will be increased, which would strengthen the role of private actions as a complement to public enforcement (which cannot deal with all infringements), delivering productivity and competitiveness to the UK economy. Moreover, we consider that it is inherently unfair to businesses who comply with the law that businesses in breach of the law are able to retain the gains from their unlawful behaviour rather than having to pay compensation. To this extent, a greater incidence of redress being provided by infringing businesses should create more of a level playing field between businesses. ${ }^{8}$

Collective redress also offers benefits to defendants, allowing them to draw a line under their liability for past events, and avoiding the cost and the vexation of having to defend the same allegations in multiple actions. From the perspective of the administration of justice, collective redress procedures help the court save valuable public resources and avoid inconsistent judgments.

Notwithstanding the general consensus about the value of collective redress, in England there has been a lively debate concerning the optimal procedures for collective actions. The debate has partly been driven by fears of introducing the excesses of 'US style' litigation. US style litigation is, of course, not a technical term, but used pejoratively to describe certain aspects of US constitutional, procedural, and substantive law including opt-out class actions, contingency fees, jury trials and the availability of punitive damages.

\footnotetext{
${ }^{8}$ Office of Fair Trading (OFT), Submission on Consumer Rights Bill 2013, 55.
} 
This 'toxic cocktail' of factors - a term even employed by the European Commission' - is said to facilitate class actions by entrepreneurial lawyers in which consumers gain little, lawyers generate substantial fees and defendants are forced into settling cases, or run the risk of large damages awards, over relatively trivial breaches. In turn this fosters a litigious society. In 2001 Lord Steyn wrote extra curially that:

There is also an unarticulated but nevertheless real conviction among judges that we must not allow our social welfare state to become a society bent on litigation. The introduction of US style class actions cannot but contribute to such unwelcome developments in our legal system. In my view the newly referred ' 2000 ' model of Group Litigation Orders is at present adequate for our purposes. ${ }^{10}$

This conviction, while far from universal, is widely shared by European business lobby groups, ${ }^{11}$ lawyers and politicians. In 2012 the European Parliament passed a resolution on collective redress calling for a horizontal legally binding framework, but declared that Europe must not copy the US approach. ${ }^{12}$ The European Commission's subsequent recommendations on principles for collective redress stated that damages claims should be constituted on an 'opt-in' basis with the express consent of class members. ${ }^{13}$ The UK Government's decision to permit class actions in competition cases departs from the European Commission's recommendations in two key respects. First, it represents a conscious decision to proceed with class actions on a sector by sector basis rather than a generic approach recommended by the EC. The Civil Justice Council had similarly

\footnotetext{
${ }^{9}$ European Commission, Press Release, 'Green Paper on Consumer Collective Redress - Europe' Memo-08-
} 741, 27 November 2008 at europa.eu/rapid/press-release_MEMO-08-741_en.htm (***date last accessed). See also L. Rickards, US Chamber of Commerce Institute for Legal Reform 'Toxic Cocktail of Class Actions' 5 September 2014 at http://www.instituteforlegalreform.com/resource/ilrs-lisa-rickard-pens-article-on-thetoxic-cocktail-of-class-actions-brewing-in-australia) (***date last accessed).

${ }^{10}$ Foreword to C. Hodges, Multi-party Actions (Oxford: OUP, 2001) iii.

${ }^{11} \mathrm{Eg}$, the European Justice Forum: www.europeanjusticeforum.org (last accessed $* * *$ ).

12 'Towards a coherent European approach to collective redress' 2 February 2012, P7_TA(2012)0021.

${ }^{13}$ Commission Recommendation of 11 June 2013 on 'Common principles for injunctive and compensatory collective redress mechanisms in the member states concerning violations of rights granted under Union Law' 2013/396/EU, Recommendation 21. For a critique of the EC's argument that 'opt-in' rules respect individual autonomy see A. Higgins and A. Zuckerman, 'Class Actions in England? Efficacy, Autonomy and Proportionality in Collective Redress' (2013) University of Oxford Legal Research Paper No 93/2013 at http://ssrn.com/abstract=2350141 (last accessed***). 
recommended the adoption of a generic opt-out procedure in 2008 but this was rejected by the Government. ${ }^{14}$ Successive UK governments have harboured concerns about the adverse economic and other impacts of a generic opt-out procedure, although these impacts have not been fully articulated beyond reference to the risk of abuse. ${ }^{15}$ On the other hand, the competition class action procedure goes beyond the EC's recommendations by allowing opt-out and not just opt-in class actions. The UK Government could rightly point to administration of justice considerations that warrant the use of opt-out class actions, in particular the need to make low value claims economically viable and to maximise recovery on behalf of victims. ${ }^{16}$ To date UK governments have recognised a need for optout class actions in two sectors, financial services and competition cases. In 2009 the Labour Government introduced a bill into parliament that incorporated an opt-out procedure for financial services claims. ${ }^{17}$ The bill reached the Third Reading stage in the House of Lords, however the class action procedure was dropped from the bill shortly before the 2010 general election, as the Government sought to get as much of its legislation passed as possible prior to the dissolution of Parliament. ${ }^{18}$ In 2012 the Coalition Government acknowledged that there may be a need for an opt-out class action procedure in competition cases, ${ }^{19}$ and, following a public consultation, committed itself to reform. The

${ }^{14}$ Civil Justice Council, Improving Access to Justice Through Collective Actions Final Report November 2008, Executive summary, 17; Ministry of Justice, The Government's Response to the Civil Justice Council's Report: 'Improving Access to Justice through Collective Actions July 2009.

${ }^{15}$ BIS, Private Actions in Competition Law $\mathrm{n} 5$ above at [5.4].

${ }^{16}$ ibid; BIS, Private Actions in Competition Law: Government Response $\mathrm{n} 3$ above, 30. This is compatible with the EC's recommendation, as it recognises that in some cases opt-out procedures might be justified (Recommendation 21) no doubt partly because a number of EU jurisdictions already permit opt-out class actions, including Portugal, Spain and Denmark.

${ }^{17}$ The bill followed a report of the Treasury, Reforming financial markets Cm 7667 (July 2009).

18 The Financial Services Bill 2009, Bill 6 09-10. See Hansard HC col 12428 April 2010 (Ian Pearson, Economic Secretary to the Treasury: 'the Government have agreed with the official Opposition through the usual channels and in the usual way which parts of the Bill should be enacted', and collective actions were a 'casualty of that process').

${ }^{19}$ BIS, Private Actions in Competition Law n 5 above, section 5. The policy process followed earlier reports on reform by BIS and its predecessor departments (eg, in November 2009 the Department of Business, Enterprise and Regulation Reform published a research report on competition cases under the class action opt- 
Government was frank in its assessment that current legal procedures for obtaining redress were not working, and practically beyond the reach of small businesses and consumers. ${ }^{20}$

The failure of England's existing collective redress procedures in the context of competition law are well documented. ${ }^{21}$ In the 2010 case of Emerald Supplies v British Airways $^{22}$ (Emerald Supplies), which arose out of British Airways involvement in price fixing of air freight cargo, the Court of Appeal effectively foreclosed the option of using representative proceedings, CPR 19.6, for price fixing claims involving both direct and indirect purchasers because of the potential conflicting interests between class members. While the Competition Act 1998 contained a dedicated opt-in class action procedure for competition cases before the CAT, such actions had to be brought by an authorised body, were confined to claims on behalf of consumers, and were limited to follow-on actions for damages in respect of previously proven anti-competitive breaches. ${ }^{23}$ Only one action had been brought under the procedure by the one body authorised to bring them, Which? against JJB Sports following the OFT’s decision to fine JJB Sports $£ 6.7$ million for fixing the prices of replica England and Manchester United football shirts between 2000 and 2001. In 2008 Which? reached a settlement with JJB Sports whereby each qualifying claimant would receive $£ 20$, the estimated illegal mark-up, but a remarkable feature of the litigation was that despite widespread publicity only 130 people - fewer than $.1 \%$ of those affected - opted into the proceeding. ${ }^{24}$ Following the case Which? effectively declared that

out regimes in Australia, Canada and Portugal), and equally significantly, calls by the regulator for opt-out class actions: Office of Fair Trading, Private Actions in Competition Law: Effective Redress for Consumers and Businesses (November 2007).

${ }^{20}$ BIS, Private Actions in Competition Law: Government Response n 3 above, 3.

${ }^{21}$ Including in the Government's own consultation document on reform, n 5 above, and the Civil Justice Council report on collective redress, n 14 above. For academic commentary see, eg, R. Mulheron, 'A Missed Gem of an Opportunity for the Representative Rule’ (2012) 23 European Business L Rev 49.

${ }^{22}$ Emerald Supplies Ltd and another v British Airways plc [2010] EWCA Civ 1284, [2010] All ER (D) 200 (Nov), upholding the decision of the High Court in [2009] EWHC 741 (Ch).

${ }^{23}$ As found by the then OFT, the Competition Appeal Tribunal (CAT), or the European Commission (EC): Competition Act 1998, old s 47A(5) and s 47A(6).

24 Although some others have settled on similar terms following the settlement, BIS, Private Action in Competition Law: Consultation on Options for Reform n 5 above at [5.4]. 
it would no longer be taking any cases under 47B because the opt-in nature of the system meant it was not a proportionate use of resources for a charitable consumer organisation. ${ }^{25}$ The organisation called for the introduction of opt-out class actions. ${ }^{26}$

The principal other collective redress mechanism - the Group Litigation Order (GLO) - was not really suitable for most competition cases either. The GLO caters for situations where a number of claims 'give rise to common or related issues of fact or law' hence it is broader in scope than the representative action. ${ }^{27}$ However the fundamental weakness in the GLO is that each claimant is required to file their own claim separately. ${ }^{28}$ As such the group litigation order is not really a class action procedure at all, but rather an effective case management tool where there are a large number of related claims, each of which justifies individual proceedings. The other major barrier to entry is that a costs order against group litigants imposes several liability for an equal proportion of the common costs ${ }^{29}$ whereas class action procedures typically exempt class members from costs liability for resolution of the common questions.

Against this background it is not surprising that both the UK Government and senior judges responsible for administering competition law in England believed there was a strong case for reform. Sir Gerald Barling, then President of the CAT, wrote an important article in the Competition Law Journal in which he noted the irony

that the underlying purpose of competition law is said to be to protect the consumer, yet in this as in other areas the ultimate consumer is normally unable or unlikely to seek recompense, even where an unlawful cartel somewhere in the chain of supply has been exposed and punished. ${ }^{30}$

\footnotetext{
${ }^{25}$ British Institute of International and Comparative Law, 8th Annual Trans-Atlantic Antitrust Dialogue, London (15 May 2008).

${ }^{26}$ Deborah Prince, then Head of Legal Affairs at Which?, quoted in R. Mulheron, 'Reform of Collective Redress in England: A Perspective of Need' Report prepared for the Civil Justice Council, 2008, 41.

${ }^{27}$ CPR $19.10-19.15$.

${ }^{28} 19 \mathrm{~B}$ PD $6.1 \mathrm{~A}$.

${ }^{29}$ CPR 46.6.

${ }^{30}$ G. Barling, 'Collective Redress for Breach of Competition Law: A Case for Reform?' (2011) 10 Competition LJ 5, 19.
} 
He went on to express the view that 'there are a number of benefits that may flow from introducing an opt-out regime.' These are: i) effective redress for consumers and businesses who are victims of anti-competitive conduct; ii) the ability to obtain legal closure for defendants subject to the possibility of claimants opting out of the litigation and iii) the ability to award aggregate damages, and as a consequence making it easier to fund such actions. $^{31}$

This push for reform came not only in the context of EU efforts towards greater harmonisation of collective redress procedures across member states, but also greater harmonisation of procedures for private enforcement of competition law, including the introduction of the 2014 Directive on Damages. ${ }^{32}$ The Directive is designed to remove practical obstacles to obtaining compensation for violation of EU competition law and to ensure that anyone who has suffered harm caused by an infringement of competition law can effectively exercise their right to claim full compensation. ${ }^{33}$

\section{The new class action procedure}

The new opt-out procedure is set out in schedule 8 of the Consumer Rights Act 2015, amending the former opt-in procedure of the Competition Act 1998. The Act is supplemented by new rules of procedure: the Competition Appeal Tribunal Rules 2015. The procedure applies only to claims brought before the Tribunal, thus excluding competition claims filed in the High Court.

Despite being limited to claims before the Tribunal, the new procedure substantially widens the types of class actions that may be brought. It permits private class action procedures covering consumers as well as businesses and both stand-alone cases and follow on claims, ie claims can be brought to establish a breach of competition law, as well as

\footnotetext{
${ }^{31}$ ibid, 19.

32 Directive 2014/104/EU of the European Parliament and of the Council of 26 November 2014 on certain rules governing actions for damages under national law for infringements of the competition law provisions of the Member States and of the European Union Text with EEA relevance. OJ L 349, 5 December 2014.

${ }^{33} \mathrm{ibid}$, Art 1; see, http://ec.europa.eu/competition/antitrust/actionsdamages/directive en.html (last accessed $* * *)$.
} 
claims seeking compensation following a finding of breach by an authorised body. ${ }^{34}$ Any private party who alleges having suffered a loss from anti-competitive conduct would be able to commence an action, ${ }^{35}$ not just authorised bodies who previously acted as champion of, and effectively gatekeeper to, collective redress for consumers. Extending the right to commence an action to directly affected class members was part of a conscious decision to make the new procedure more accessible to consumers and small businesses. ${ }^{36}$ The Tribunal will also have the power to authorise non class members to act as a representative claimant - paving the way for trade unions and NGOs to perform this function - but only where the Tribunal considers it 'just and reasonable' to do so. ${ }^{37}$ During the consultation the Government indicated that it supported truly representative bodies acting as a representative claimant, as opposed to special purpose vehicles created specifically for the action, which is a device commonly used in Europe. ${ }^{38}$ This preference is reflected in the procedural rules for the Tribunal, which require it to consider whether a body proposing to act as a class representative is a pre-existing body and what its functions and duties are. ${ }^{39}$ A person or body who seeks to act as a representative claimant - whether in a standalone or follow on claim - must satisfy a number of criteria. These include: whether they are adequate to perform the role, would perform it fairly, have the resources to pay the defendant's recoverable costs if ordered to do so or satisfy an undertaking as to damages where an interim injunction is sought, and have no material conflict of interest with class members. ${ }^{40}$ The Tribunal must also consider whether the proposed representative has a plan for conducting the proceedings, notifying, communicating and consulting with class members, and funding arrangements. ${ }^{41}$ A collective proceeding can only be continued if the Tribunal makes 'a collective proceedings order' 42 and the Tribunal may make such an order

\footnotetext{
${ }^{34}$ Consumer Rights Act 2015, sched 8, s 47A.

${ }^{35}$ ibid, s 47B(8).

${ }^{36}$ BIS, Private Actions in Competition Law: Government Response n 3 above at [5.28].

${ }^{37}$ Consumer Rights Act 2015, sched 8, s 47C(8).

${ }^{38}$ BIS, Private Actions in Competition Law: Government Response n 3 above at [5.32].

${ }^{39}$ CAT rule $78(3)(b)$.

${ }^{40}$ CAT, rule $78(2)$.

${ }^{41}$ CAT, rule $78(3)$.

${ }^{42}$ Consumer Rights Act 2015, sched 8, s 47B(4).
} 
only 'in relation to claims the Tribunal considers raise the same, similar or related issues of fact or law and are suitable to be brought in collective proceedings. ${ }^{43}$ If the Tribunal makes a collective proceedings order the order must a) authorise the person who brought the proceedings to act as the representative of the class b) describe a class of persons whose claims are eligible for inclusion in the proceedings, and specify whether the proceedings are opt-in or opt-out proceedings. Only UK domiciles can be covered by an opt-out claim; non UK claimants would have to opt in to proceedings. ${ }^{44}$ To improve the viability of low value claims, and to ensure proportionate use of court resources, the Tribunal will have the power to make an aggregate damages award. ${ }^{45}$

The Tribunal is not permitted to award exemplary damages ${ }^{46}$ or make cy-pres awards. Any unclaimed sums from a damages award would be paid to a charity designated by the Lord Chancellor. $^{47}$ The parties remain free to settle cases on a cy-pres basis, or with reversions to the defendant, or any other destination (which would include a third party funder) subject to approval by the Tribunal. The Tribunal must approve a collective settlement as fair and reasonable. ${ }^{48}$ While third party funding is permitted, the Government prohibited the use of damages based agreements for opt-out proceedings, ${ }^{49}$ and retained two way cost shifting. ${ }^{50}$ Similarly, security for costs orders may be made against the representative claimant if there is 'reason to believe that the claimant will be unable to pay the defendant's costs if ordered to do so. ${ }^{51}$

The Government indicated its commitment to encouraging use of ADR procedures in its response to the public consultation process, but stated that such procedures were a supplement to, and not a substitute for, a formal legal process allowing victims of anti-

\footnotetext{
${ }^{43}$ ibid, s 47B(6).

${ }^{44}$ ibid, $\mathrm{s} 47 \mathrm{~B}(11)$.

${ }^{45} \mathrm{ibid,}$ s $47 \mathrm{C}(2)$.

${ }^{46}$ ibid, s 47C (1).

${ }^{47} \mathrm{ibid}$, s $47 \mathrm{C}(5)$. The current designated charity is the Access to Justice Foundation.

${ }^{48}$ ibid, s 49A(5).

${ }^{49}$ ibid, s 47C(8).

${ }^{50} \mathrm{CAT}$, rule $98(1)$.

${ }^{51}$ CAT, rule 59(5)(f).
} 
competitive conduct to bring claims on a collective basis. ${ }^{52}$ The Act contains provisions allowing the court to make a collective settlement order, and approve a proposed 'collective settlement' even where a collective proceedings order is not made, provided the Tribunal considers the terms of the settlement just and reasonable. ${ }^{53}$

In broad outline, therefore, the new class action procedure contains all the features that were identified by Sir Gerald Barling to make the system work. ${ }^{54}$ A procedure that allows for privately initiated opt-out class actions on a stand-alone or follow on basis, with the power vested in the Tribunal to award aggregate damages, promotes both effective access to court for claimants and finality for defendants. On closer inspection, however, some of the provisions of the Act appear to have been drafted with only limited regard to the commercial realities of how private actions are funded, and how the court should deal with the legal problems invariably thrown up by competition collective redress claims. These issues are further examined below.

\section{MANAGING CONFLICTING INTERESTS}

One potential weakness of the new procedure is that it does not address how the Tribunal can and should manage the kind of intra group conflicts that proved fatal to the Emerald Supplies representative proceeding. This is an important issue because conflicts of interest between claimants arise frequently in competition cases. As already noted, Emerald Supplies was a representative action that involved admitted price fixing by British Airways and other international airlines in respect of air freight cargo. British Airways was required to pay substantial fines by both the US Department of Justice and the European Commission for its involvement in the cartel. ${ }^{55}$

Not surprisingly, a number of civil actions seeking redress for affected consumers and businesses were also launched. In Emerald Supplies the claimant company, which used the services of BA to import flowers, brought a representative action on its own behalf and on

52 BIS, Private Actions in Competition Law: Government Response n 3 above, 49-50.

${ }^{53}$ ibid, s 49B(1) and (8).

${ }^{54}$ Barling, n 30 above.

55 United States Department of Justice, Press Release, 1 August 2007; European Commission, Press Release, 9 November 2010 (IP/10/1487). 
behalf of all other direct or indirect purchasers of air freight services affected by the price fixing. The relief claimed was a declaration that damages were recoverable 'in principle' from the defendant by those purchasers in respect of three types of loss: (i) the inflated element of the price insofar as it was passed on to them; (ii) loss of sales volume insofar as the inflated price was passed on by them to their own buyers; and (iii) loss of sales volumes of other products as a result of brand damage. BA applied for an order striking out the representative element of the claim. The Vice Chancellor and subsequently the Court of Appeal upheld the application on the ground that the persons that the claimant sought to represent did not all have the same interest so as to meet the preconditions of a representative action under CPR 19.6. Moreover, it was not possible to say of any given person that he was a member of the class because membership depended upon the success of the action. Even if this defect could be remedied by amendment of the pleadings, the relief sought in the action was not equally beneficial for all class members, because it included persons who had absorbed the alleged inflated price as well as those who had passed it on. This created divergent and possibly conflicting interests. ${ }^{56}$

It is debatable whether this aspect of the decision is sound. The claim in Emerald Supplies was not for damages but for declarations of liability in respect of losses suffered by both direct and indirect customers. It is possible there was a conflict in the potential size of recovery from those who did, and did not, pass on the damages, but the court was not being asked to assess damages. Instead the claim was intended to achieve significant cost savings by obtaining a declaration on liability issues for a broad group of interested persons without the need for each of them to issue their own claim. ${ }^{57}$ A favourable judgment could then be used as a basis for all interested persons to pursue a damages claim against the defendant, either in individual proceedings or some other collective action, or as the basis for settlement negotiations. This creative approach to CPR 19.6 had been followed previously by Vinelott $\mathrm{J}$ in Prudential Assurance Co Ltd $\mathrm{v}$ Newman Industries Ltd. ${ }^{58}$ However it did not appeal to the Court of Appeal who were evidently concerned that CPR

\footnotetext{
${ }^{56}$ Emerald Supplies $\mathrm{n} 22$ above at [64], [69].

${ }^{57}$ The claim was issued before the European Commission's decision to fine British Airways and other carriers involved.

${ }^{58}$ Prudential Assurance Co Ltd v Newman Industries Ltd [1979] 3 All ER 838, [1981] Ch 29.
} 
19.6 provides relatively few tools to ensure adequacy of representation for represented persons with different interests. The lack of procedural safeguards in CPR 19.6 is the principal reason why the courts have interpreted the 'same interest' requirement narrowly. ${ }^{59}$

Unfortunately, the new class action procedure is ambiguous on the treatment of intra-class conflicts, and thus whether an Emerald Supplies type claim could be certified. There is nothing to indicate whether, or when, class certification may be appropriate notwithstanding the existence of conflicting interests between some group members. This may be a harsh criticism of the legislation given that other class action regimes do not expressly deal with the treatment of intra-class conflicts either. The difficulty with the English procedure is that the silence in the Act is coupled with some ambiguity in the rules. Rule 78 provides that a person cannot be a class representative cannot if they have a conflict of interest with class members in relation to the common issues. ${ }^{60} \mathrm{~A}$ class representative is defined to include a sub-class representative. ${ }^{61}$ The use of sub-classes is a crucial technique designed to ensure the interests of subsets of class members are protected where their interests diverge or conflict with other class representatives, however it is unclear whether the 'no conflict' rule prevents any intra-class conflict, or only conflicts of interest between the class representative (or sub-class representative) and the class or subclass they are representing. If the former interpretation is correct, sub-classes could only be used to manage divergent interests among class members; if the latter interpretation is correct, it could be used to deal with the sorts of conflicts that proved fatal to the Emerald Supplies proceeding. The rules do not shed much light on the issue, rule 78 merely provides that a sub-class representative can be appointed to represent 'a sub-class of persons whose claims raise common issues that are not shared by all the represented persons' ${ }^{62}$ On the other hand, some of the provisions regarding sub-classes make sense in contexts where there are at least potential conflicts between class members, such as the power of the Tribunal to order class or sub-class representatives to give disclosure to other class

\footnotetext{
${ }^{59}$ J. Seymour, 'Representative Procedures and the Future of Multi-Party Actions' (1999) 62 MLR 564.

${ }^{60}$ CAT Rule 78(2).

${ }^{61}$ CAT rule 2. The rules make detailed provision for the use of sub-classes: rule 75(3), 78(4), rule 80, rule 81, rule 88 , rule 89 , rule 91 , rule 98 .
}

${ }^{62}$ CAT rule $78(4)$. 
members. ${ }^{63}$ While disclosure is not confined to parties who are formally opposed to each other, it does provide one of its core rationales: to promote equality of arms so that each party is not taken by surprise or at a disadvantage vis a vis their opponent in presenting their case. ${ }^{64}$ The power of the Tribunal to certify a class action notwithstanding any intraclass conflicts could have been put beyond doubt if the rules stated that the class representative must not have a conflict of interest with class members in relation to the common issues unless a sub-class representative is also appointed to represent those members.

For the reasons outlined below, it is suggested that claims involving intra-class conflicts should ordinarily be certified by the Tribunal, and Tribunal should use subclasses, and its broad case management powers, ${ }^{65}$ to ensure that all class members are adequately represented. Divergent and conflicting interests are common in mass harm cases, ${ }^{66}$ and of all the collective redress procedures currently available in England, opt-out class actions provide the best means of mediating the conflicting legal interests of all persons with a claim (or defence) arising out of the same situation, and the public interest in consistent and efficient adjudication. The concern animating the Court of Appeal's decision in Emerald Supplies is that a claim comprising both direct and indirect purchasers could result in the interests of some class members not being adequately represented because the representative party might advance a case that undermines other members' interests. This concern about adequacy of representation has been a recurring theme in the courts' jurisprudence on representative actions for a century. ${ }^{67}$ While the concern is legitimate, it fails to take account of an unavoidable feature of collective redress: the problem of adequacy of representation will always arise whenever numerous persons have claims

\footnotetext{
${ }^{63}$ CAT rule 89.

${ }^{64}$ A. Zuckerman, On Civil Procedure (London: Sweet \& Maxwell, $3^{\text {rd }}$ ed, 2013) [15.2]; Beheer BV v Netherlands (1994) 18 EHRR 213.

${ }^{65}$ CAT rules 19 and 88 .

${ }^{66}$ As Mulheron observes 'virtually all classes will have some characteristics in common and some unshared characteristics ...', R. Mulheron, The Class Action in Common Law Legal Systems (Oxford: Hart, 2004) 164.

${ }^{67}$ See, eg, London Association for Protection of Trade v Greenlands Ltd [1916] 2 AC 15, HL; R. Mulheron, 'Emerald Supplies Ltd v British Airways plc: A Century Later, The Ghost of Markt Lives On' (2009) 8 Competition Law Journal 159.
} 
arising out of the same, similar or related circumstances, regardless of the form of the proceeding/s in which those claims are resolved. Even where proceedings are brought individually, how an individual argues their claim has the potential to either advance or prejudice the claims of others who are similarly situated. ${ }^{68}$

A court cannot avoid conflicts of interest arising between victims in an alleged mass harm situation simply by refusing to allow the litigation to be conducted on a group wide basis. While this may avoid intra-group conflicts in the case before the court, where these conflicts reflect different legal interests of different claimants, the courts will invariably be confronted with those conflicts again if all the victims insist on bringing a claim, as is their right. The Emerald Supplies case is a perfect example. Assume that, following the decision not to allow the proceeding to continue as a representative action because of the conflicting interests between direct and indirect purchasers, two separate representative actions were launched against British Airways, one comprising only direct purchasers and the other comprising only indirect purchasers. If multiple purchasers in the same supply chain all claimed to have absorbed the inflated prices a conflict arises whether the claims are determined in the same court room or separate court rooms. In the latter scenario, every subsequent court that hears an issue which was already decided by another court has the dilemma of choosing between: i) compromising the litigants' due process right to be heard to ensure its decision is consistent with previous findings, ie, reaching the same result regardless of the argument or evidence put forward by the litigants; or ii) allowing claims or defences to be advanced that are inconsistent with previous findings thereby potentially undermining the substantive law and public confidence in the correctness of judicial decisions.

This dilemma may be somewhat ameliorated by the doctrine of precedent. Where the earlier court decided a question of law, other prospective litigants acting rationally would appreciate that the chances of successfully overturning a binding precedent are slim and choose not to throw their good money after someone else's bad. ${ }^{69}$ However, the

${ }^{68}$ A fact that is widely acknowledged (Ontario Law Reform Commission, Report on Class Actions (1982) 486) but its implications for the appropriate design of class action procedures have not been fully explored.

${ }^{69}$ Taylor v Sturgell 553 US 880, 128 S Ct 2161 (2008). 
possibility that the court which hears an issue for the first time will create a precedent effectively disposing not only of the claim before it but the claims of others who are similarly situated, strengthens the argument for utilising a procedure where the legal interests of all affected persons are adequately represented when that issue is first determined. Moreover, whether a subsequent court chooses to hear a claim again without regard to the findings made by the earlier court, or conducts the case in a manner that ensures consistency with the earlier findings, both involve some waste of public and private resources. In short, a court cannot escape the dilemma of how to manage conflicts of interests between claimants (or defendants) by allowing some claimants and defendants to have their cases determined independently. The same conflicts will re-emerge across different legal proceedings, and with the additional downside of creating irreconcilable conflicts between the public interest in consistent judicial decisions, proportionate use of court resources, finality of litigation and litigants' due process right to be heard. By ruling out the possibility of group litigation due to conflict of interests, the court denies itself the ability to effectively manage a multiplicity of claims in such a way that the result in any one proceeding does not unfairly prejudice the interests of other litigants, either claimants or defendants, and/or undermine the substantive law and the administration of justice.

This was one of the reasons why, in the 2013 case of Infineon Technologies v Option Consommateurs, ${ }^{70}$ the Supreme Court of Canada upheld the certification of a competition price-fixing class action that comprised both direct and indirect purchasers of computer microchips. The defendant challenged certification on the ground, inter alia, that the inclusion of both direct and indirect purchasers meant there was a risk of double recovery. The Court noted that a class action would avoid both over and under recovery: 'In the instant case, there is no risk of double recovery, since the direct and indirect purchasers would be combined in a single group that would make a single collective claim of an aggregate loss. ${ }^{, 71}$ The class members clearly shared a common interest in establishing the aggregate loss and in maximizing the amount of this loss. It would then be a matter for the alleged victims at a later stage of the proceedings to establish whether they are entitled to damages and, if so, their respective shares. In short, the Supreme Court endorsed the very

\footnotetext{
${ }^{70}$ Infineon Technologies v Option Consommateurs 2013 SCC 59.

${ }^{71}$ ibid at [115].
} 
procedure that the English Court of Appeal held was not available in the Emerald Supplies case.

The SCC's decision in Infineon is an acknowledgement that collective procedures are the best means of protecting the legal interests of large numbers of people affected by the same alleged wrong as well as the person/s accused of committing them. English law has the same preference for completeness in adjudication. This finds expression in case law, ${ }^{72}$ procedural rules on case management, and legislation such as section $49(2)$ of the Supreme Court Act 1981 which requires the court to

so exercise its jurisdiction in every cause or matter before it as to secure that, as far as possible, all matters in dispute between the parties are completely and finally determined, and all multiplicity of legal proceedings with respect to any of those matters is avoided.

Yet historically English law has lacked the full array of legal procedures required to give effect to this general objective in mass harm cases. The new class action procedure for competition cases represents a real milestone in English lawmakers' efforts to fill this lacuna. Although the Act does not expressly give the Tribunal the power to certify class actions involving conflicting interests with the aim of finally determining the entire dispute, there is nothing prohibiting the Tribunal from adopting this approach. Even if the power was put beyond doubt by amendment to the rules, achieving completeness in adjudication wherever practicable will still require a change in judicial attitudes because of the discretionary nature of the certification process. One positive aspect of the new procedure is that when making a collective proceedings order, the Tribunal must describe or otherwise identify the class and any sub-classes; and describe or identify the claims certified for inclusion in the collective proceedings. ${ }^{73}$ The power to define the class means that the Tribunal can prevent the exclusion of claims that should properly be included in the proceeding. This would be an effective way of avoiding overlapping or rival class actions brought by rival funders, which are not uncommon in other jurisdictions. ${ }^{74}$

\footnotetext{
${ }^{72}$ See, eg, Henderson v Henderson [1843-1860] All ER Rep 378, (1843) 3 Hare 100, 114-115.

${ }^{73}$ CAT rule $80(1)(\mathrm{c})$ and (d).

74 V. Morabito, 'Clashing classes down under - evaluating Australia's competing class actions through empirical and comparative lenses' (2012) 27 Conneticut Journal of International Law 245.
} 


\section{CERTIFICATION PROCESS}

One of the principle safeguards of the new class action procedure to prevent abuse is a strong, mandatory, judicial certification process. The main criteria have been outlined in above, but it is worth recapping how the system works:

a) To be eligible for certification the action must be brought on behalf of an identifiable class ${ }^{75}$ which satisfies commonality criteria, ${ }^{76}$ and is suitable to be brought in collective proceedings. ${ }^{77}$

b) In determining whether a claim is suitable the Tribunal will take into account all matters it thinks fit including a non-exhaustive list of factors such as 'the costs and benefits of continuing the collective proceedings', whether it is suitable for an aggregate damages award, the size and nature of the class, and whether separate proceedings by class members have already been commenced. ${ }^{78}$

c) If a court makes a collective proceeding order it must also decide whether to certify the proceeding on an opt-out or opt-in basis, taking into account all matters it thinks fit, and two additional factors are expressly identified: the strength of the claims and the estimated damages that individual class members may recover. ${ }^{79}$

While no one could quibble with a general suitability rule in the abstract, exactly how the rule will be applied in practice is difficult to predict, especially given that all other collective redress procedures available were deemed not fit for purpose, at least in competition cases. It seems strange to introduce a new legal procedure on the grounds that existing procedures do not work for small businesses and consumers, and then require those small businesses and consumers to prove that the existing procedures are not suitable in order to take advantage of the new one.

\footnotetext{
${ }^{75}$ CAT rule $79(1)(\mathrm{a})$.

76 The claims of class members must 'raise common issues' (CAT rule 79(1)(b), meaning 'the same, similar or related issues of fact or law' (CAT proposed rule 72(2)(f), Consumer Rights Act 2015, sched 8, s 47B(6)).

${ }^{77}$ CAT rule 79(1)(c); Consumer Rights Act 2015, sched 8, s 47(6).

${ }^{78}$ CAT rule $79(2)$

${ }^{79}$ CAT rule 79(3)(a) and (b).
} 
Some obvious questions arise when trying to apply these criteria. From whose perspective is the cost/benefit analysis made? Presumably this is not a reference to the costs borne by the class representative who is the party applying for a collective proceedings order and is willing to bear these costs. Nor could it be class members who are immunised from the costs of representing the class as a whole. ${ }^{80}$ If, by contrast, it is a reference to the cost to the defendant, or costs to the public purse, this would effectively allow the Tribunal to rewrite the substantive law by exercising a procedural discretion. Notwithstanding the existence of an arguable claim, the Tribunal would be able to declare that the amounts in dispute are so low that the game is not worth the candle. ${ }^{81}$ This seems the most reasonable interpretation of the cost-benefit rule, but also the most radical for it transforms procedure from the servant of substantive law into its master. Advocates of this approach acknowledge it means that 'the imperfections of life' are worn by the victims and not those responsible for committing the breach that caused them. ${ }^{82}$ In addition, a residual discretion to not allow meritorious claims to proceed gives rise to a risk of reduced compliance if businesses perceive that there is a zone of tolerated non-compliance. As the Ontario Court of Appeal observed in certifying an over-charge class action in Cassano v Toronto Dominion Bank: 'It would hardly be sound policy to permit the defendant to retain a gain made from a breach of contract because the defendant estimates its costs of calculating the amount of the gain to be substantial. ${ }^{83}$ Plans to implement a similar 'it ain't worth it' rule in the United States were ultimately dropped over concerns about its implementation and difficulties in deciding which cases weren't worth it and which were. ${ }^{84}$

\footnotetext{
${ }^{80}$ CAT rule $98(1)$

${ }^{81}$ Some courts in other jurisdictions have applied a cost-benefit analysis in this way, see, eg, Lacarde v Ontario (Minister of Community \& Social Services) (2003) 65 OR (3d) 289 (SCJ).

${ }^{82}$ W. Pengilley, 'Class actions: a legislative hammer to crack a nut?' [1988] Law Society J 28, 30.

${ }^{83}$ Cassano v Toronto Dominion Bank [2007] ONCA 781, 87 OR (3d) 481 at [49]. See also Markson v MBNA Bank [2007] ONCA 334, 85 OR (3d) 321. For a detailed discussion of the issues raised by a cost-benefit rule in certification decisions see Ontario Law Reform Commission, n 68 above, 411-416.

${ }^{84}$ D. Hensler et al, Class Action Dilemmas: Pursuing Public Goals for Private Gain (Santa Monica, CA: Rand Institute for Civil Justice, 2000) Executive Summary, 16; Judicial Conference Committee on Rules of Practice and Procedure, Minutes of Meeting of 6-7 October 1997.
} 
Similarly, a question arises as to what exactly a collective proceeding should be superior to? If a case raises genuine issues of fact or law that are common to multiple claims, there may be scope for debate as to which collective redress procedure is most suitable in a given case, eg, joinder, test case, representative proceeding or class action. For the reasons outlined above, however, the public interest in the administration of justice will always be better served by deciding all claims in the same proceeding than a procedure that involves multiple determinations. The relevance of some of the 'suitability criteria' are also debatable. The availability of ADR makes little sense as a factor because while ADR may be a very effective mechanism for resolving disputes without the need for litigation, using the availability of ADR to deny class certification will almost certainly result in unfair settlements favouring defendants, because without the option of seeking redress through the courts victims will have limited or no bargaining power in the ADR process. ${ }^{85}$ As the Government rightly noted in its response to the consultation on private actions in competition law ADR is a supplement to, not a replacement for, court adjudication. ${ }^{86}$

Notably absent from the inclusive list of 'suitability criteria' is an express merits test, ie whether the claims have reasonable prospects of success. This is odd given that the strength of the claims is identified as a factor at a stage of the inquiry where it is of doubtful relevance: choosing between certifying the class as either an opt-in or opt-out action. Neither opt-in nor opt-out procedures are more suited to dealing with strong claims on the one hand, or weak claims on the other. From a procedural standpoint, either a claim is worthy of court adjudication or it is not. Under either procedure, a court can use its case management powers to require some particulars of some of the claims to be provided in order to assess their strength. What changing the form of the procedure can do is to change the numbers and stakes involved, and hence the viability of the action, as well as the probability of further litigation dealing with the same issues. The choice between an opt-in and opt-out procedure depends on the weight to be given to a range of factors including finality of litigation, efficient and proportionate use of public and private resources, the economic viability of the action, and adequacy of representation for class members. It is

\footnotetext{
${ }^{85}$ Settlement only class actions in the US and the Netherlands are criticised on this basis: see, eg, H. Erichson, 'The Problem of Settlement Class Actions' (2014) 82 George Washington Law Review 951.

${ }^{86} \mathrm{BIS}$, Private Actions in Competition Law: Government Response n 3 above, 49-50..
} 
only in relation to the last criterion that opt-in class actions represent a superior procedure because all members of the class are known through their express choice to participate. Accordingly all class members know of the proceedings and have the opportunity to communicate with class counsel and, subject to case management considerations, with the court directly, as to how they want their interests to be protected.

Returning to a preliminary merits test for certification, the rules do require that a representative claimant state in the claim form that 'he believes the claims have a real prospect of success' ${ }^{87}$ The subjective nature of this requirement seems akin to the role performed by 'statements of truth' in the Civil Procedure Rules, where litigants are required to affirm their honest belief in the claims (or defences) and evidence submitted. ${ }^{88}$ However the claim form for a collective proceeding must also contain a statement of truth, ${ }^{89}$ suggesting that the assertion of belief in the merit of the action is intended to perform some additional role. It might be possible for the Tribunal to read into this requirement the need for reasonable grounds to support the representative claimant's belief, injecting some welcome objectivity into the merits test.

A preliminary merits test can be criticised as redundant because the summary judgment procedure is already designed to weed out claims that have no reasonable prospects of success, and therefore do not warrant further investment of court resources. ${ }^{90}$ Nonetheless, the value of an express preliminary merits test at the certification stage is that it focuses the Tribunal's mind on the most important safeguard against abusive claims. A robust preliminary merits test is the best, and most tailored, safeguard against the risk of 'blackmail suits' ${ }^{\prime 91}$ - a phenomenon where weak claims are used to extract settlements from defendants who are worried about the publicity and unrecoverable costs of defending such

\footnotetext{
${ }^{87}$ CAT rule $75(2)(\mathrm{h})$.

${ }^{88}$ CPR 22.1(4); Zuckerman, n 64 above at [7.118].

${ }^{89}$ CAT rule $75(4)$.

${ }^{90}$ CPR 24, CAT rule 43.

${ }^{91}$ C. Hodges, Response to Private Actions in Competition Law: A Consultation on Options for Reform (July 2012) 10.
} 
suits, as well as the potentially ruinous consequences if, contrary to expectation, the claim is ultimately upheld by a court. ${ }^{92}$

The combined effect of the rules on certification is considerable uncertainty for all interested parties. Even if the mandatory criteria are satisfied, the outcome of a certification application is difficult to predict given the Tribunal's open ended discretion whether to certify a collective proceeding and, if so, whether on an opt-out or opt-in basis, taking into account a list of non-exhaustive criteria which lend themselves to considerable satellite litigation. ${ }^{93}$ The main cost of this uncertainty is that it could deter prospective claimants and prospective funders from incurring the expense and time involved in launching a claim and applying for a collective proceedings order. At a conference organised by the British Institute of International Comparative Law to discuss reactions to the new procedure, one litigation funder ventured that they would likely only consider funding class actions after certification was granted. ${ }^{94}$ This does not bode well for the procedure's success as much of the cost of funding class actions lies in getting them off the ground before any proceedings have commenced, including investigations, legal research, and communications with potential class representatives and class members. As with the management of conflicting interests, whether the certification process proves to be successful in weeding out weak claims whilst providing sufficient predictability to those funding meritorious ones, will depend principally on judicial attitudes to the new procedure.

\section{FUNDING RULES}

The biggest threat to the viability of the new class action procedure is that, in seeking to avoid abuse through unfair pressure on defendants or exploitation of class members, the

\footnotetext{
${ }^{92}$ For a notable example where class certification was denied on this ground, see the judgment of Posner $\mathrm{J}$ in Rhone Poulenc Rorer F.3d 1293 (7th circuit 1995).

${ }_{93}$ Similar to that which occurred in the courts interpreting the nine non-exhaustive factors identified in CPR3.9 on relief from sanctions: see, eg, A. Higgins, 'The costs of case management: what should be done post-Jackson?' (2010) 29 CJQ 317; J. Williams, 'Well, that's a relief (from sanctions)! - Time to pause and take stock of CPR r.3.9 developments within a general theory of case management' (2014) 33 CJQ 394.

${ }^{94}$ British Institute of International and Comparative Law conference, 'Consumer Rights Act 2015 - The UK Class Action: A Reaction' 21 April 2015.
} 
Act does not permit the contractual freedoms, nor confer on the Tribunal the necessary powers, to make funding class actions financially viable.

Before discussing these limitations, it is worth summarising the cost and funding rules that apply to the new class action procedure. The new procedure retains the general rule of English costs law that the losing party is liable to pay the winner's legal costs. ${ }^{95}$ However in common with other commonwealth class action regimes, ordinary class members who might not participate in or even be aware of the action, are immunised from any potential adverse costs liability. Instead liability of adverse costs is borne by the class representative. ${ }^{96}$ In most cases, therefore, the liability that a representative claimant faces in terms of costs incurred in representing the class and the defendant's costs in opposing the claim will dwarf the representative claimant's own financial interest, ie their damages claim. To transform the otherwise crazy decision to be a representative claimant into a rational choice, representative claimants need access to commercial funding and usually some form of indemnity from their funder against the risk of an adverse costs order if the case fails. Even in the absence of a commercial indemnity, third party funders in England are liable for adverse costs up to the amount of their own investment in the case. ${ }^{97}$ Accordingly, access to commercial funding is usually critical for collective actions, and the costs and risks to funders are substantial. However, under the new procedure, the financial incentives for potential funders to take on class actions are deliberately limited.

The Act prohibits damages based agreements for opt-out collective proceedings, although this restriction is ameliorated by the fact that third party funding, also typically conducted on a contingency basis, is permitted. More significantly, the Act circumscribes the Tribunal's power to award costs and success fees to the representative party - and through them, the funder - to compensate them for the time, expense, and risk they bore in leading and funding the (successful) action. Without such a power, the 'free rider' problem present in any collective action looms large: the person acting on behalf of the class usually risks a great deal for little personal gain, with the class free riding on their representative's

\footnotetext{
${ }^{95}$ CAT, rule $98(1)$.

96 ibid.

${ }^{97}$ Arkin v Borchard Lines Ltd (Costs Order) [2005] EWCA Civ 655, [2005] 1 WLR 3055.
} 
efforts. Failing to adequately compensate those who bear the costs and risks of collective action obviously jeopardises the utility of the procedure.

Other jurisdictions with class action procedures are acutely aware of the inequity of the free rider problem and the risk that, left unchecked, it could result in under use of the procedure. Borrowing concepts for trust law and restitution, the US courts have developed a 'common fund' doctrine, where even without statutory authority or a contractual relationship between class members and the class representative, the court can award fees to class counsel acting for the representative claimant out of the damages awarded to the class as a whole. In Boeing Co v Van Gemert, the Supreme Court stated that, '[t]he doctrine rests on the perception that persons who obtain the benefit of a lawsuit, without contributing to its cost, are unjustly enriched at the successful litigant's expense,' and went on to observe that it 'prevent[s] this inequity by assessing attorney's fees against the entire fund, thus spreading the fees proportionately among those benefited by the suit' ${ }^{98}$

Canadian jurisdictions have statutory provisions that allow class counsel, but not third party funders, to recover their fees out of any monetary award or settlement fund in favour of the class. Ontario, for example, has what is described as a 'first charge' for the solicitor in respect of an enforceable agreement with a representative party regarding costs and disbursements. ${ }^{99}$ Moreover, some Canadian courts have used their general power to make an 'appropriate order for the fair and expeditious determination of the case' to approve a funding agreement that allowed the third party funder to claim a success fee in the event of a settlement or award to the class. ${ }^{100}$

A similar power in Australia's class action legislation has not yet been successfully utilised by third party funders ${ }^{101}$ (contingency fees are not permitted in Australia), although

\footnotetext{
${ }^{98}$ Boeing Co v Van Gemert 444 US 472 at 478 (1980). See also Re Zyprexa Prods Liability Litigation 594 F.3d 113, 129 (New York Court of Appeals, 2010), 'class members who do not hire counsel nonetheless benefit from any recovery. The doctrine thus prevents the unjust enrichment of these class members at the expense of class counsel by compensating counsel in proportion to the benefit they have obtained for the entire class, rather than just the named class representatives with whom they contracted.'

${ }^{99}$ Ontario’s Class Proceedings Act 1992, s 32(3).

100 ibid, s 12; Dugal v Manulife Financial Corp [2011] ONSC 1785; (2011) 105 O.R. (3d.) 364.

${ }^{101}$ R. Mulheron, ‘Third Party Funding and Class Action Reform’ (2015) 131 LQR 291, 300.
} 
the possibility has been noted in at least one case. ${ }^{102}$ As a consequence the primary funding model used in Australia are opt-in class actions where all group members are required to sign a funding agreement with the third party funder as a condition of class membership. ${ }^{103}$ Such 'tied classes' have been upheld by the Full Federal Court as compatible with the letter, if not the spirit, of Australia's opt-out class actions regime. ${ }^{104}$ However the cumbersome and expensive option of establishing tied classes - with all the transaction costs that go with locating and signing up eligible class members ${ }^{105}$ - may not be available under the new class action procedure in England where the choice of opt-in or opt-out procedure is vested with the Tribunal, and not the representative claimant. ${ }^{106}$

The UK Parliament was not unaware of the 'free rider' issue when debating the Consumer Rights Bill, but the solution it adopted in section 47C(6) is a curious one that may ultimately fail to address the problem, creates a different problem, and is difficult to justify in principle. Section $47 \mathrm{C}(6)$, introduced as an amendment to the bill in the House of Commons, allows the class representative to claim for the costs and legal expenses (which presumably would include a funder's 'success fee') for representing the class. However, the crucial qualifying condition is that such fees can only be awarded out of unclaimed damages. ${ }^{107}$ In other words, the provision does not allow a class representative or their funder to obtain a fee from 'free riding' class members who recover damages for the risk incurred in successfully backing and bringing the case. Rather, it only allows the class representative (and thus the funder) to take some of the damages awarded to class members

102 Pharm-a-Care Laboratories Pty Ltd v Commonwealth of Australia (No 6) [2011] FCA 277. Courts have also sometimes awarded additional 'compensation payments' to class representatives for the financial and non-financial burdens and risks they incurred: see V. Morabito, 'An empirical and comparative study of reimbursement payments to Australia's class representatives and active class members' (2014) 33 CJQ 175.

${ }^{103}$ Morabito, $\mathrm{n} 74$ above.

${ }^{104}$ Multiplex Funds Management Limited v P Dawson Nominees Pty Limited [2007] FCAFC 200.

${ }^{105}$ Admittedly these transaction costs are continually falling with advances in communications technology.

${ }^{106}$ Mulheron, n 101 above, 305-306.

${ }^{107}$ Section $47 C(6)$ provides that '... the Tribunal may order that all or part of any damages not claimed by the represented persons within a specified period is instead to be paid to the representative in respect of all or part of the costs or expenses incurred by the representative in connection with the proceedings.' 
who, despite having a ticket to ride, don't get on the class action bus at all to claim their damages entitlement.

There are two main flaws with this creative approach; one practical and one theoretical. First, it makes the financial viability of funding opt-out class actions dependent upon some of the affected persons not claiming the compensation to which they are legally entitled. Supporters of this rule could point to past experience in other jurisdictions where the numbers of eligible class members who claim their damages entitlement is often considerably less than 100 per cent, although data on 'take-up' rates is limited because such information is usually private and not a matter of public record. Some pertinent observations about take up rates were made by the Ontario Superior Court in Hislop v Canada (Attorney General): 
[T] he reality is that there has never been a class proceeding that has had $100 \%$ participation by class members. Class proceedings where there is a high level of participation generally involve cases where there is a known finite group such as patients of a physician. ... I accept [the] submission that it is rare that a class action has more than a 75\% take-up rate. To date, despite a well-funded notification campaign and the notoriety of the trial judgment in this case only 500 class members [of 1500] have come forward. ${ }^{108}$

While it may be accepted that take up rates of 100 per cent are unlikely in most cases, a funding mechanism that relies on eligible persons not exercising their legal rights to claim compensation is not a reliable business model. This is especially so in a jurisdiction where claims management companies are active, and could (correctly) advertise to class members that they can help them recover their rightful compensation risk free, and that if they don't claim, the money will go to lawyers and litigation funders instead. In addition, the funding model will not work in opt-in class actions, or in contract based opt-out class actions where details of eligible class members are held by the defendant, such that very high or 100 per cent take up rates are achievable without class members having to take any additional steps to claim their damages entitlement. In short, the more that is known about the victims of an alleged competition law breach, the less likely their claim will attract third party funding.

The funding mechanism under section $47 \mathrm{C}(6)$ also creates a clear, and entirely avoidable, conflict of interest between the class representative (and the funder standing behind them) and class members if the claim is successful. The representative and funder has an obvious financial interest in having fewer class members come forward to claim compensation so that the damages 'pot' is not diluted to the point where there are insufficient funds to cover the representative claimant's costs including any success fee. While the process of communicating with class members, including as to the distribution of damages, is always under the control of court, the inevitable lack of enthusiasm of the funder could have a material impact on take up rates. While one distinguished commentator has cast doubt on this possibility, ${ }^{109}$ a useful thought experiment to test the idea is to ask whether the take up rates would increase if one of the factors the court took into account in determining the size of a success fee is the number of eligible class members that claimed

\footnotetext{
${ }^{108}$ Hislop v Canada (Attorney General) Ont SCJ 30 April 2004 at [17].

${ }^{109}$ Mulheron, n 101 above, 309.
} 
their damages entitlement. If it is plausible that at least some funders would go the extra mile to encourage eligible class members to claim their damages in order to increase their own recovery, it is also plausible that giving funders a financial incentive to discourage take up rates would negatively affect those take up rates.

The theoretical justification for limiting section $47 \mathrm{C}(6)$ to unclaimed damages is that the new opt-out procedure is based on the principle of recovering full compensation for victims of competition law breaches, which is now enshrined in the EU Directive on Damages. It would be unacceptable, so the argument goes, to give funders a 'first charge' on the damages awarded to the class leaving the victims worse off than they would have been but for the breach. ${ }^{110}$ Yet this defence merely serves to underline the contradiction inherit in the funding model permitted by section $47 \mathrm{C}(6)$; the provision only works where there is less than full compensation to the class because eligible class members did not claim their damages entitlement. It is these unlucky 'non-riders' who end up paying for the free riding class members savvy enough to get on the class action bus. In this regard there is some tension between section 47C(6) and one of the principal reasons for having an opt-out procedure. Lawmakers in other countries who have adopted an opt-out system were conscious of the fact that in some cases, either due to a lack of financial incentive or understanding of the legal process, many eligible persons would not choose to 'opt-in' to class actions. Opt-out procedures are partly designed with these passive victims in mind, and to facilitate recovery on their behalf without their active involvement in the proceeding. ${ }^{111}$ By contrast, section $47 \mathrm{C}(6)$ only works if passive class members do not come forward to claim their 'full compensation'. The funding mechanism requires the opposite outcome to that which the procedure is designed to promote.

While section 47C(6) might fail on its own terms, cost and funding rules that do not deliver 'full compensation' to successful claimants cannot be classified as a failure or

\footnotetext{
110 ibid, 310 .

${ }^{111}$ See, eg, Commonwealth of Australia, Parliamentary Debates, House of Representatives, 14 November 1991, 3174-5 (Michael Duffy, Attorney General 'The Government believes that an opt out procedure is preferable on grounds both of equity and efficiency. It ensures that people, particularly, those who are poor or less educated, can obtain redress where they may be unable to take the positive step of having themselves included in the proceedings.')
} 
inconsistent with the EU Directive on Damages. The problem stems from English law's tendency to define full compensation as not just a person's entitlement to all damages recoverable for breach of legal rights, but also compensation for the costs of vindicating those legal rights through court adjudication. Yet funding rules that require litigants to contribute at least part of the costs of their own access to justice are an inevitable feature of any efficient and equitable model for funding access to justice where legal aid is limited. This was one of the major lessons of Lord Justice Jackson's landmark costs review in 2010. It is structurally impossible to devise a privately funded legal system that provides full compensation for successfully pursuing or defending a claim and which is accessible and fair to both claimants and defendants. ${ }^{112}$ The reason is that the legal process, being designed to determine disputes between litigants with reasonably arguable claims and defences, is inherently uncertain, and legal costs are unaffordable for most households and small businesses. ${ }^{113}$ To make the system accessible third party funding is essential. Accordingly, funders must be rewarded for their investment in successful cases, and be able to cover the costs of unsuccessful cases so that, across the portfolio of arguable cases they fund, they make a reasonable return. The difficult question is who should pay for the financial incentives that must be built into the system and bear the risks that are inherent in it? The most logical answer would be the litigants, typically claimants, who benefit from these funding arrangements. However this would mean that successful claimants would be left with less than their 'full compensation' entitlement once their legal costs are paid. For nearly 15 years in England the full cost of access to justice for many claimants was funded by unsuccessful defendants who had to pay the claimant's actual costs, a success fee of up to 100 per cent of base costs to the claimant's lawyer if they were operating on a conditional fee agreement, and the insurance premium paid by a claimant for to cover an

112 This may have been what the UK Supreme Court was referring to when it stated in Coventry v Lawrence No 3 [2015] UKSC 50 at [72] per Lord Neuberger and Lord Dyson MR that ' $\ldots$ in the absence of a widely accessible civil legal aid system (which had ceased to exist by 1999), it is impossible to devise a fair scheme which promotes access to justice for all litigants'.

${ }^{113}$ In his final report on the costs of civil litigation Sir Rupert Jackson cited evidence that $73 \%$ of all UK households have savings of less than $£ 10,000$, whereas legal costs for just one litigant can be many times higher than $£ 10,000$ in fully-contested litigation: Jackson, $\mathrm{n} 7$ above, Ch 1 at [1.2]. 
adverse costs order should their claim fail. ${ }^{114}$ Claimants on CFAs litigated risk free. This guaranteed access to court for all claimants, and full compensation for successful claimants, but came at great and ultimately disproportionate cost to defendants and their insurers who had limited capacity to control the costs for which they were ultimately liable. The inefficiency, unfairness, and potentially chilling effect this had on defendants has been decried by virtually everyone, including the Supreme Court, the European Court of Human Rights and Lord Justice Jackson. ${ }^{115}$ The distinction between an entitlement to full compensation for breach of a substantive legal right, and rules allocating the costs of resolving disputed claims, ie access to justice, is both practically necessary and defensible in principle. Damages are awarded for infringements of rights, while seeking a court adjudication of arguable claims and defences involves no legal wrong, and is in fact the exercise of a constitutional right. ${ }^{116}$ The question of who should pay for the exercise of these constitutional rights is quite separate from the question of whether one party has wrongly infringed the right of another, and if so, what is the full value of that right in damages.

One of Lord Justice Jackson's key recommendations in his costs review was that it was untenable for defendants to go on bearing the risk that claimants suing them might be unsuccessful, and that successful claimants would need to bear some of the costs of funding their own access to justice. ${ }^{117}$

Section 47C(6) gets half of this prescription right by not imposing the risk of claimants' losing their cases on defendants, but it has echoes of the distortions and inequities of the recoverable CFA regime. Instead of imposing the risk inherent in funding claims on the successful claimants who benefit from the funding, section $47 \mathrm{C}(6)$ imposes

\footnotetext{
${ }^{114}$ For a description of the system see Jackson, ibid, Chs 9 and 10.

115 Coventry v Lawrence n 112 above, although the Supreme Court, by a majority of 5 to 2 stopped short of declaring the system incompatible with the right to fair trial under ECHR, Art 6: [2015] UKSC 50; MGN Limited v United Kingdom (App no 39401/04) [2011] ECHR 66; Jackson, ibid, Chs 9 and 10.

${ }^{116}$ Protected by the right to fair trial under ECHR, Art 6.

117 Jackson, n 7 above, Executive Summary, xvi-xviii.
} 
the costs on 'unsuccessful' claimants; unsuccessful not because their claims failed, but because they did not claim their damages entitlement. ${ }^{118}$

In a legal system dependent on private funding, the costs of funding successful claimants' access to justice has to be borne, at least in part, by those same claimants (typically by pledging some of the value of their claims in return for legal assistance). In collective redress contexts, the most efficient and equitable means of achieving this objective is to give the Tribunal the power to award the representative party some of the costs of representing the class out of the damages awarded to the class. This is not a 'first charge', but a conditional fee for service, and in the absence of contract, the amount of the success fee would ultimately be determined by the court. The language of 'first charge' is also misleading to the extent that it suggests that the funder's success fee necessarily takes priority over class members' damages entitlements. The success fee can be made dependent upon class members being awarded damages (or obtaining a settlement) and the size of the fee is invariably linked to the size of recovery by class members. Empirical research in the US has found that courts focus on proportionality when deciding class counsel's fees; the amount of client recovery is overwhelmingly the most important determinant of the attorneys' fee award. ${ }^{119}$

The preceding discussion also highlights the illogicality of banning contingency fees in opt-out proceedings. The motive for the ban was no doubt partly to avoid the perceived cocktail of factors that leads to 'US style' litigation. The Government also

${ }^{118}$ Of note is that the Act is silent as to whether success fees can be paid to funders in judicially approved settlements (as opposed to awards of damages at trial). A Tribunal might therefore be willing to contemplate approving a settlement that included a direct payment to a funder as a success fee, but such a proposal would be extremely controversial and liable to challenge as not 'fair and reasonable' within the meaning of the Act. A proposal for a success fee to be automatically paid to a funder out of the compensation that would otherwise have gone to class members would fall foul of the spirit of $47 \mathrm{C}(6)$. On the other hand, a proposal for a success fee to be paid as part of the recoverable costs payable to the class representative is likely to be carefully scrutinised by the Tribunal because, on its face, it would be irrational for a defendant to agree to such a proposal when even were it to lose at trial, it would not be legally liable to pay a success fee.

119 T. Eisenberg and G. Miller, 'Attorneys Fees in Class Action Settlements: An empirical study' (2004) Journal of Empirical Legal Studies 1; B. Fitzpatrick, 'An Empirical Study of Class Action Settlements and Their Fee Awards' (2010) 7 Journal of Empirical Legal Studies 811. 
rejected contingency fees on the grounds that this would not promote access to justice for claimants with modest damages claims, as lawyers would only focus on high value claims that have strong prospects of success. ${ }^{120}$ Here again, there is a structural weakness in the arguments in favour of 'opt-out class actions with brakes', or at least systems that employ the wrong type of brakes. ${ }^{121}$

The concern about profit driven class actions overlooks why collective action procedures are needed in the first place. In most mass harm cases redress is unobtainable because no individual has suffered losses large enough to motivate them to litigate, even if the collective interest is substantial. To make obtaining legal redress economically viable, collective action needs to be possible and profitable. As the US Supreme Court observed in Amchem Products v Windsor,

The policy at the very core of the class action mechanism is to overcome the problem that small recoveries do not provide the incentive for any individual to bring a solo action prosecuting his or her rights. A class action solves this problem by aggregating the relatively paltry potential recoveries into something worth someone's (usually an atttorney's) labor. ${ }^{122}$

Despite the economies generated by collective action procedures, funding them is rarely cheap and rarely without risk. Unless the profit incentive is built into the procedure it is bound to fail to achieve its primary aim of facilitating collective redress where individual litigation would not be viable. In the US the courts recognise that the attorney's fee should reflect the risk they undertook in representing the class. ${ }^{123}$ It is precisely the building in of 'incentives to litigate' that most alarm opponents of class actions. The European Justice Forum, a lobby group founded and comprised of major multi-national companies,

\footnotetext{
120 BIS, Private Actions in Competition Law n 5 above, 5. A majority of respondents to the consultation agreed with the proposed ban although many were highly critical for both legal and practical reasons. The submissions are available at https://www.gov.uk/government/consultations/private-actions-in-competitionlaw-a-consultation-on-options-for-reform (last accessed 12 September 2015). ***only here.

121 The terminology was employed by R. Mulheron, 'Justice Enhanced: Framing an Opt-Out Class Action for England' (2007) 70 MLR 550.

122 Amchem Products Inc v Windsor 521 US 591, 617 (1997).

${ }^{123}$ Higher risk cases results in higher than average fees, but lower risk results in lower than average fees: Eisenberg and Miller, n 119 above.
} 
acknowledges that class actions will not be utilised without liberal funding rules, but argues that if the opportunity for financial gain from litigation is sufficient to attract finance it is also sufficient to carry the risk of abuse. ${ }^{124}$ While making courts more accessible to claimants, and funding access to justice more profitable to third parties, invariably creates a risk that some litigants and funders will try to abuse the system, this claim proves too much. The absence of an incentive to litigate also provides incentives to multi-national companies to breach competition and consumer laws either deliberately or through underinvestment in compliance initiatives at the expense of those who buy or use their goods and services. The profit incentive in private litigation might act as a valuable counter-weight to the profit incentive to breach standards where there is limited public enforcement. The OFT, which until recently was the public regulator tasked with enforcing competition law in the UK, candidly acknowledged in its submission on class actions that 'public enforcement cannot deal with all breaches'. ${ }^{125}$ The benefits of private enforcement of anti-trust law were also highlighted in a recent review by US scholars Davis and Lande. They assessed the contradictory criticisms levelled at private enforcement - that it is unproductive because it fails to provide even minimal compensation to victims or effective deterrence, and that it is counterproductive because it leads to over-compensation, sometimes of the wrong people, and over-deterrence. They concluded that private enforcement provides 'enormous benefits' as it is virtually the only way for victims of antitrust breaches to obtain compensation, and provides real deterrence. ${ }^{126}$

This research provides support for the UK Government's decision to facilitate greater private enforcement of competition law, however its decision to ban contingency

124 www.europeanjusticeforum.org (last accessed $* * *$ ). Hodges, whose work is partly funded by the European Justice Forum, makes an identical point: Hodges, n 91 above, 12.

125 OFT, n 8 above, 55.

126 J. Davis and R. Lande, 'Defying conventional wisdom: the case for private antitrust enforcement' (2013) 48 Georgia Law Review 1, 79. For the debate over the value of private versus public enforcement, see, eg, W. Wils, 'Should Private Antitrust Enforcement Be Encouraged in Europe?' (2003) 26 World Competition 473; P. Nebbia, 'Damages actions for the infringement of EC competition law: compensation or deterrence?' (2008) 33 European Law Review 23; C Hodges, 'European competition enforcement policy: Integrating restitution and behaviour control. An integrated enforcement policy, involving public and private enforcement with ADR' (2011) 34 World Competition 383. 
fees in opt-out proceedings is difficult to fathom, even if one accepted the rationale for banning contingency fees. This is because contingency fees are not the cause of the main criticisms levelled at opt-out class actions, and partly because contingency fees actually go some small way to addressing them. Contingency fees and opt-out class actions are like oil and water. In opt-out class actions there does not need to be a lawyer-client relationship, which creates an acute principal agency problem by increasing the likelihood that class counsel put their own interests before those of the class. ${ }^{127}$ As a consequence, there can be significant disparity of recovery by the agent/lawyer on the one hand, and the class/principals on the other in class action settlements. ${ }^{128}$ Contingency agreements between lawyers and claimants if anything ameliorate rather than exacerbate this problem because they are only possible in the context of a formal lawyer-client relationship. It may be that a client's interest in their case is so modest that they do not seek to exert any influence over how the lawyer conducts the case, but the legal mechanism to do so is still there. $^{129}$ Given their contractual nature, one has to query whether the prohibition on contingency fees in opt-out proceedings will have any effect at all, or is merely a symbolic safeguard. Nor is it a strong argument against contingency fees to suggest that they lead lawyers to focus on only high value claims. No one argues that one funding model works or would be employed for all cases, in the same way that no one method of payment works for all business transactions. Rather, a range of funding models is needed to ensure that all claims with merit are able to be pursued, and contingency fees are an attractive option for many claimants who need or wish to use some of the value of their claim to fund its prosecution.

While historically there have been concerns about giving lawyers a stake in the outcome of their client's case, conditional and contingency fees are now widely accepted as

${ }^{127}$ See, eg, A. Miller, 'Some Agency Problems in Settlement' (1987) 16 JLS 189.

${ }^{128}$ An infamous example are coupon settlements where attorneys can be paid substantial fees whilst class members are awarded coupons that are only redeemable for more goods from the defendant. This practice has been significantly restricted in the US by the Class Action Fairness Act of 2005.

${ }^{129}$ Issacharoff argues that obliging class counsel to use commercial litigation funding may be an effective way to reduce agency costs, because funders have sufficient incentives to monitor class counsel, and the same interest as class members in maximising damages recovery: S. Issacharoff, 'Litigation funding and the problem of agency cost in representative actions' (2014) 63 DePaul Law Review 561, 566. 
a necessary, if not attractive, model for funding access to justice. ${ }^{130}$ Contingency fees are an exercise of freedom of contract, and without this freedom many persons with distinctly arguable legal claims would be unable to assert them. ${ }^{131}$ The Government agreed with Lord Justice Jackson's recommendations to make damages based agreements available in a broader category of cases, ${ }^{132}$ while Jackson is pressing the Government to go further still. ${ }^{133}$ Regrettably, this collective judgement was rejected when it came to funding options for the new class action procedure.

\section{CONCLUSION}

Overall, this 'third generation' class action statute for competition cases is a considerable improvement on what preceded it, but the success of the new regime will depend in large measure on a change in judicial attitudes to the types of cases that are suitable for collective resolution. It is suggested that aspects of the new procedure still have not got the balance right between facilitating meritorious claims and deterring abuse and could result in continued under-enforcement of competition law. First, the procedure is ambiguous as to how the Tribunal can and should deal with intra-class conflicts of the kind that proved fatal to the Emerald Supplies representative proceeding. Secondly, the Tribunal's broad discretion as to whether to certify a collective proceeding as opt-in, or opt-out, or at all, creates considerable uncertainty particularly from the viewpoint of potential representative claimants and funders. Thirdly, the funding rules place unjustified limits on sources of funding and create further uncertainty as to whether the representative claimant, and ultimately the person funding them, will be reimbursed for the time, expense and risk of bringing the proceeding. By seeking to provide victims with 'full compensation' for breaches of competition law, there is a real possibility that the Act will deter potential class

${ }^{130}$ Campbells Cash and Carry Pty Ltd v Fostif Pty Ltd [2006] HCA 41 (Campbells Cash and Carry); BVerfG, 1 BvR 2576/04 vom 12.12.2006 (German Constitutional Court struck down a law providing an outright ban on contingency fees as incompatible with the right of access to court); Jackson, n 7 above, Chs 11 and 12.

${ }^{131}$ Campbells Cash and Carry ibid at [120] per Kirby J.

132 Jackson, n 7 above, ch 12; Courts and Legal Services Act, s 58AA; Damages-Based Agreements Regulations 2013.

${ }^{133}$ Lord Justice Jackson, 'Fixing and funding the costs of civil litigation' (2015) 34 CJQ 42. 
representatives and funders from coming forward to represent those victims in the first place. 